\title{
Dalmatian Monuments in German 19 Century Travel-records - Ida von Düringsfeld
}

\author{
Ivana Popović
}

Department of Arts and Restoration, University of Dubrovnik, Croatia

Copyright $\bigcirc 2017$ by authors, all rights reserved. Authors agree that this article remains permanently open access under the terms of the Creative Commons Attribution License 4.0 International License

\begin{abstract}
Travel literature sometimes can be very important source of data about the art heritage of the nation whose regions are being described. Many foreigners who traveled in Dalmatia were fascinated by the abundance of its cultural and natural splendour. In 1852 Ida von Reinsberg-Düringsfeld published travel-record Aus Dalmatien in which she presented Dalmatia to the world as a cultural-historical landscape. Nowadays some of them are really useful if you want to studying history of Dalmatian art, but also history of art history in Dalmatia.
\end{abstract}

Keywords Travel Literature, Ida von Reinsberg-Düringsfeld, Dalmatia, Cultural-historical Landscape, Art History

\section{Introduction}

Travel-record is a special literary genre in which the writer presents his or her impressions and observations about countries, regions and cities he travels through. Some of them are an important source of data referring to perception and attitude towards the art heritage of the nation whose regions are being described and which can be of great use when reconstructing real life and appearance of a city.

Dalmatia has always been visited and in travel-records publicly described by foreigners. They were fascinated by the abundance of its cultural and natural splendour. Dalmatia were always the places where foreigners very often coming to visit, and as a result of visiting our country were travel books, some of which can be extremely useful to art historians and analyzing their data.

There, we can find a lot of historical, ethnographic, geographic and other useful information and facts. Many travel writers are not satisfied with only to describe a foreign country that has inspired them, some of them also puts in their books geographic maps or lithography.

Travels flourished in $19^{\text {th }}$ century. Due to general feeling of longing for something far away and unknown, for freedom and challenges of Romanticism, but also due to political reasons, artists and writers sought their inspiration in distant and exotic lands.

When we finished with the analysis of texts, we come to the conclusion, that almost all writers are impressed with cultural heritage of Dalmatia. One positive shock and disbelief. Almost everybody is surprised at the amount of art and monuments of Dalmatian towns.

Some travel books are written in a very interesting way, such as Ida Reinsberg-Düringsfeld, famous German novelist. Thanks to some travel literature, it may be reconstructed a life in particular Dalmatian area. Travel writers took notes about the impressions during their travels. German passengers were quite a large number and some of them are well-known name. One of them was Ida von Düringsfeld.

In 1852 Ida von Reinsberg-Düringsfeld published travel-record Aus Dalmatien in which she presented Dalmatia to the world as a cultural-historical landscape and as an unusual cultural environment.

Common starting point for all writers is the assumption that the Dalmatia is primitive, backward, poor and very dangerous country for foreigners. However, during his stay in Dalmatia, the opinion is changed, on better!

\section{Ida's Itinerary and Her Vision of Dalmatia}

\subsection{Ida's Arrival in Dalmatia}

German writer Ida von Reinsberg-Düringsfeld (15. 11. 1815, Militsch, Schlesien - 25. 10. 1876 Cannstatt, Stuttgart) arrives in Dalmatia in autumn 1852. together with her husband Otto and young son Mark[5]. J. G. Kohl's book about Dalmatia won the German audience, also including her. She traveled to Dalmatia with steamship, where she will remain almost two years.

She became friends with a lot of famous people in Dalmatia and she was very often a guest in their homes. While Ida stayed in Zadar, she met many famous citizens. 
One of them was doctor and cultural worker Ante Kuzmanić (1807-1879) who was very famous citizen of Zadar. She also visited family Lantana in her mansion on the island of Ugljan, where she describes their furniture and paintings. Ida will, during his stay in Stari Grad on Hvar, have the opportunity to become friends with Peter Nisiteo who lived in Hektorović Tvrdalj and there she will describe the house, pond and her famous and beautiful garden.

All of this discovers and gives us an idea about its preference for the visual arts and especially architecture. In every city where Ida was stayed, she went to visit cultural attractions and also she and met and described famous citizens like Ivan Stazić, Ana Vidovic, Ivan August, Anthony Kaznačić, Mato Vodopic, Medo Pucića, Pasko Kazali, Francesco Carrara.

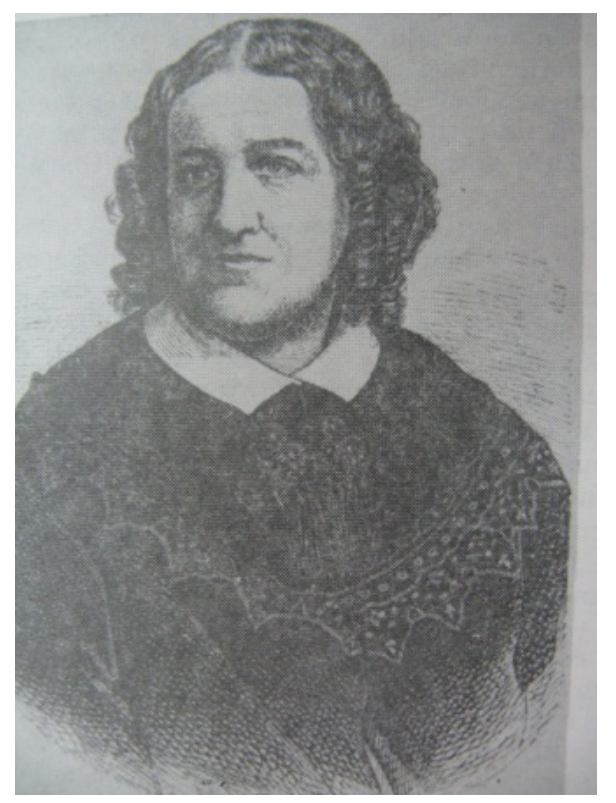

S1. 01. Ida von Duringsfeld

In her travel book Aus Dalmatien, printed in Prague in 1857. her husband Otto collect all relevant geographical, economic, historical, cultural and historical data, while the main text contains her thoughts, thinking about the country and the people that they have met and got to know. Descriptions are very interesting, accompanied by lucid thinking and witty remarks, the itinerary is certainly very pleasant to read. Thanks to Ida, just like thanks to Kohl, Dalmatia was opened to the world as a cultural and historical landscape and as an unusual social environment.

She was self-taught and already as a little girl she wrote poems. She spent her childhood on the estate of his mother near Herrnstadtand she studied singing and foreign languages and as a very young girl, she began to publish poems in Abendzeitung. Mother's estate was its main source of funding in her life and also it enabled her carefree life.

In Dresden, Ida was met with writers and experienced first success in the literary field. The first collection of poems published in $1853 \mathrm{~g}$. after waiting followed by a series of short stories and novels and translations of songs.

1845. Ida marries eight years younger Prussian officers and baron Otto von Reinsberg (Torgau, 12. 5. 1823 - suicide Cannstadt, Stuttgardt, 26. 10. 1876) and they live together or to the estate of her mother or traveling in Europe. Together with her husband carried out 20 years wandering life and her husband will be very useful in her work travel writing. Otto will retire from the army and devoted to the study of folk customs and folk life of people in regions whose travels. 1846. They had a son Mark who is traveling together with his parents.

Ida until 1845 published his works (poems, short stories and several novels) under the pseudonym Thekla. For his historical novels, such as Margarethe von Valois und ihre Zeit (Leipzig, 1847) and Antonio Foscarini (Stuttgart, 1850) has long studied the cultural and historical material.

After returning from a trip to Italy and Switzerland she has published the poetic images of Venice Am Canal Grande (Dresden, 1849) and travel books Aus der Schweiz (Bremen, 1850), Aus Italien (Bremen, 1851). Before she arrived to Dalmacija, Ida published a collection of poems Für dich (Leipzig, 1851) and translations of Czech folk poetry Böhmische Rosen (Breslau, 1851).

When Ida, in the summer of 1852. arrived in Dalmatia with her husband Otto Reinsberg and their son Marko , after many trips to France, Italy, Germany, Switzerland and Belgium, Ida von Düringsfeld was already well established writer in German literary circles .

Ida is often compared to George Sand because of its learning and agility. She was a woman full of self-confidence, safe and energetic, elegant and high stature with a round face framed black curly hair [1]. She was a self-taught writer who spoke several Slavic and Romance languages and during the stay in a country she studied its history and folk customs. And her husband Otto, now retired after marriage, also devoted himself to the study of folk customs and folk life. She also tried to traduce some of Dalmatians poems [8].

With her education, style and originality in display regions through which he passed, Ida is one of the most interesting and the most read and most often referred to travelers who have traveled our country, such as Fortis, Cassas and Kohl. Ida's style of writing is very different from the peaceful and precipitated Kohl. It is lively and playful, aphoristic and witty and full of associations.

1852. Ida comes for the first time on the Dalmatian soil where she will remain 18 months, but Dalmatial was not completely unknown for her. A lot of foreign travelers are visiting our country, particularly Dalmatia, and some of them described their impressions in the itineraries that are published and readily available to the reading public. Ida belonged to the reading public. She read them and cited some names of travel writers in her works, such as the name of Alberto Fortis, Stieglitz, Kohl Neigebaura, Carrara.

She has read the most important works of Dalmatian writers and this way, she learned the history of our country and, what is very important and of particular importance for 
us, art historians, she learned about the cultural monuments in Dalmatia[1].

Ida was very direct and hearty, eager to conversation, she was always happy to communicate with the local inhabitants of our regions, which for her was an inexhaustible source of information. She also was a friend of ordinary people and the intellectuals in the literary, cultural and political life of Dalmatia. She was always surrounded with them knew with whom they fought a brisk, skillful and profound discussions of literature and art.

During her stay in Dalmatia, Ida tirelessly absorbed impressions and asked about the customs and culture of each place where she was. She always used to say that when she is visiting a city it is one kind of rule to go visit a museum of that city. During her stay in Zadar she declared: "It is also came a young professor of literature, which Otto met him in hause of Mrs. Cattani. He offered me to show the museum tomorrow. For me, visit to the museum is obligation, not pleasure." [2].

Ida has many useful data, information and advice received from the people she met and with whom he associated.

In Zadar, Ida and her husband are hunging out with others writers and intellectuals like dr. Kuzmanić, Josip Ferrari-Cupilli, in Split with Ivo Franceschi and Bajamonti, in the Stari Grad with Šime Ljubić and Petar Nisiteo, and in Dubrovnik with Ivan Kaznačić, brothers Pucic, Antun Kazali, Mato Vodopić. All of they are all highly appreciated the woman who has absorbed all obtained data and that her own experience of Dalmatia poured into travelogue Aus Dalmatien.

Ida's last residence in Dalmatia was Dubrovnik from where they will travel in late February 1854 . Who knows whether Ida even longer stay in Dubrovnik that it did not happen personal tragedy. The reason for her rapid departure was the death of her daughter Zorka born in Dubrovnik on the 15th June 1853 and who died on January 30, 1854. Because of some childhood diseases, a few days after that unfortunate incident follows another shock - her mother's death.[9]

Her stay in Dalmatia resulted in numerous friendships of which are maintained even after her departure. [1]

At November 291857 Šime Ljubic write his first review of the work of Ida, her Aus Dalmatien in Zadar newspaper Osservatore dalmato from 01 October 1856. In which he praises Ida because she discovered to the world the beauty of Dalmatia in a way that is fundamentally different than some of her predecessors.[1]

Also, a prominent pharmacologist and editor of the Zadar magazine Zora Dalmatinska Ivan August Kaznačić informed shortly before, in July, the Dalmatian cultural public with the person, Ida von Durinsfeld, and work of the German writer and her plain purpose in coming to the idea that her knowledge of Dalmatia share with European audiences.

Of course, there were also complaints like those Ivan Kukuljević Sakcinski: "The work Düringsfeld I read, but believe me I'm sorry for the time spent. In three thick books, she talks incessantly about his senses, the collapse of an apartment and eating, the certain people who he was and that sometimes compromised and describes wrong. "[10]

The piece Aus Dalmatia written in three volumes and together comprises 635 pages of Ida's text and 250 pages of notes of her husband Reinsberg. Kukuljević was therefore right when he spoke of the extensive of the piece. But we should not ignore the fact that Ida and Otto in Dalmatia stayed a year and a half and during that time visited whole Dalmatia, from Zadar to Kotor. They both wanted to get to know their readership with the beauty and picturesque Dalmacija and their experiences and adventures.[1]

Croatian scientists who have studied work of Ida and her figure are Nada Beritić and her Dalmatinske teme Ide von Duringsfeld in the Annals of the History Institute of the Academy of Dubrovnik from 1970. and prof. Ivan Pederin that analyzes activity of Ida in his books and articles related to German travel writing. Of course, there are also other scientists who have mentioned Ida during her stay in Dalmatia, but generally they are related on research "Beritić - Pederin" like prof. Petricioli, Miroslav Despot, Kresimir Čvrljak, Ivo Peric ... I need to mention that in all of these works Ida is analyzed and observed mainly as a writer without much reference to her vision of our art with the exception of Ivo Petricioli's Stari Zadar u slici i riječi what is very useful for us, art historians.

\subsection{ITINERARY: Skradin, Krka, Šibenik, Zadar, Split, Dubrovnik, Kotor....}

In early August 1852, spouses are sailed with ship from Trieste to Dalmatia. The journey takes them along the coast of Istria through Mali Lošinj to Zadar. After a short stay in Zadar they traveled through Zemunik to Benkovac and Skradin in the area Morlakia, and then they went to Krka and Šibenik. In early September they arrived in Split, and they also visited Trogir.

In the first days of 1853 , they sailed to the south cost of Dalmatia and a short time were in Hvar and the Stari Grad and across Korčula come to Dubrovnik in early spring 1853. In Dubrovnik they remain almost a full year and they were absent only when they visited Cavtat and the Boka kotorska.

All Dalmatian places that Ida was visited by boat, steamboat, carriage, on foot or on a donkey, they found a place in her work Aus Dalmatia were she gives descriptions of nature, folk costumes and history or literature. She has tirelessly sought, collected and translated folk songs of Dalmatia. The great importance to us is also Otto's notes. At the end of each volume of travelogues and for each chapter separately, Otto brings historical development of cities and other localities, describes the most important cultural monuments. He brings significant biographical information of persons mentioned by Ida, writers, writers, historians, scientists, politicians and church dignitaries and he reflects on their work and activities of states and the sources from which he draws its information. 
Right at the beginning of his travel writing he says about Dalmatia that is very small and that it only takes three days for visit it and take whole tour [3]. There were a small number of travel writers like couple Düringsfeld-Reinsberg who stayed in Dalmatia for a year and a half and during that time traveled along the Dalmatia from Zadar to Kotor. They truly wanted to know Dalmatia and its knowledge transfer to Europe. Despite their genuine desire for travel and adventure spirit, a lot of friends and acquaintances tried to talk them out of travel in Dalmatia, fortunately without success.

Their friend and editor Triester Zeitung, Franz Ernst Pipitz wanted to stop them to go in Dalmatia because it is barbaric country full of adventure [4].

Also, spouses have not come to Dalmatia with the recommendation of an Austrian Minister as was the case with Kohl [5], so, indeed, they were a little bit dubious and the governor of Austria Lazar Mamula asked for information about the couple Düringsfeld-Reinsberg.

In August 1852, a married couple Düringsfel-Reisberg goes on a journey to Dalmatia. Departing from Trieste, along with his young son Mark, they travel along the coast of Istria through Mali Lošinj to Zadar. After a short stay in Zadar, they go through Zemunik and Benkovac to Skradin. They choosing just like this itinerary because they personally wanted to check on the Morlakija (Adriatic-dalmatian hinterland) and to make sure it is exactly as how others have testified, raw and notorious. According Ida's opinion, some of stories were exaggerated. She explains that during her stay in Zadar she had several opportunities to convince the cordiality of the local population.[16]

Ida was met with Dalmatia through the literature since she was a child and she now sees it as an area exactly described like in all this books, barren land, wasteland and out of the way. The shepherds who keep their sheep in the cruel nature did not enter at all liveliness in nature. And at the same time Velebit bora additionally tiring and reinforces negative impression [4]. Dalmatia has a rich vegetation, but poor soil.

Late in the night, they arrived in Skradin and stayed in the tavern, which had two free rooms. Ida describes Skradin as the seat of judges, place of 300 houses and 1,150 inhabitants, of which a large part is the Orthodox faith. The population is mainly deals with trade or agriculture, but you can see very easily poverty of people [4]. They visited and Sradinski Buk, who is considered one of the most beautiful waterfalls in Europe and enchanted with the beauty of the Krka river and vegetation around the river and life in accordance with the river, referring to the ingenuity of the people who use the power of the river for washing and to power mills [4]. Ida is very impressed by the life in harmony with nature, whose admiration is very easy to see by reading her descriptions of Dalmatian towns [3].

She saw Dalmatia as a very simple geographic region: there are sea, islands, cost and mountains. It is very simple, just like people, simple and primitive. Reading her work, it is easy to conclude how she is very educated and how she knows some facts of the history of Dalmatia. Also, it is very quickly came to the conclusion that coast and islands exudes Italian character and hilly area that is away from the sea have oriental, eastern influence. She notes the difference in mentality of inhabitants of the sea zone and people from the continent [3].

Ida was a literary extremely knowledgeable and in her style of writing can be found similarities with some German writers. It can be seen familiarity with Goethe or Heine in the description of visiting the family Lantana in her mansion, summer residence on the island Ugljan where she describes the details of their salon, furniture, pictures. Devastation of villa began after the Second World War and quite changed the look of the villa. Its architecture was designed so that it is aligned with nature. [3] The romantic atmosphere that she describes it is disappeared. There are only traces. The family archive of family Lantana is located in the State Archives in Zadar and artworks are in Zadar city museum. [11] Except rich inventory we must mention the portrait of Simeon Lantana, which may be work of Rafo Martini (1771-1846), painter from Dubrovnik [11], and also is very interesting watercolors of amateur painter Giuseppe de Lantana where he shows romanticism and beauty of villa Lantana and nature. [12]

She is very impressed with the architecture in the city of Zadar. She praises the Venetians, their tendency to elegance and practicality of building and also praises Frenchman who left a good road to all Dalmatia [3].

Šibenik by her opinion is a city where you can see a lot of things, though at first sight it does not look nice. She describes the fortress of St. Nicholas and the cathedral is the pride of Dalmatia [3].

During her stay at Split, she was thrilled with connection port and the hills because "she never she had never seen such a great city with so beautifully colored background"'[3]. She will visit the Salona, Diocletian's Palace, city churches, nearby villages and islands [3]. At insola Hvar she visited famous Tvrdalj of Petar Hektorović and with her romantically eyes and brain she combines famous owner, art and the past and history.[15] Split Ida sees and perceives like peasant town with badly and poor educated population, especially women. It is less cultured than Zadar and Dubrovnik. It's a city without theatres and literature where young men are leaving to Padova to study law or medicine and where women dress very nicely but they do not go out except when they go to the church. [13]

In the spring of 1853, Ida and Otto together with her son Marko arrived in Dubrovnik [3]. Coming from one destination to another, they usually had the recommendation of who should contact for help with finding accommodation and initial orientation in the new environment. In Dubrovnik, that was Luigi Serragli, merchant, Italian Consul, the most influential activist in Dubrovnik Trade and Crafts Association [6]. He was their first landlord, godfather to their second child and helped them to find a more permanent home for them and two underage children [6]. Ida made friends with his landlady Anna very quickly and also she 
quickly learned the Croatian language.

Ida was very quickly and very well adapted in environment of Dubrovnik. She considered Dubrovnik as a extremely cultural city.[14] She compared Dubrovnik with Split and for her, Split was more cruder and more violent, as opposed to Dubrovnik which is, according to her, was culturally mature and tamer. She saw this fact while she was watching her son Marko: "In Split he did not know anything other than throwing the stones, and in Dubrovnik, he became the most polite kid in the world"'[3].

Ida became friend very quickly with owner of the house where she lived in Dubrovnik and thanks to her, Ida learns Croatian language very fast. For the architecture of the house Ida writes that it was like almost all others typical houses in Dubrovnik's suburb, with two floors and ground floor, terrace and garden where owner do not planted flowers. Her friend Ana plants just one rose and a lots of cabbage.[3]

Her Dalmatian journey she concludes with reflections that Zadar is a city of the present, Split city of the future. Zadar has the German spirit, Split Italian and Dubrovnik is most Slavic. Trogir is a piece of the Venetian Middle Ages, Split a piece of Venice, Šibenik was romantic, and Kotor is it still romantic.

A lots of time, a great source of satisfaction were nocturnal walks the city walls, as was the case in Zadar [3], or enjoying observe the ruins of old buildings in the moonlight [3]. It is obvious that Ida is under the influence of Romantic spirit.

Ida comes in Dalmatia from a country that has just industrialized, so, she is passionately looking for past in Dalmatia, culture and customs and many traditions which are origin of Venice, but can not be seen in Venice. In that her kind of orientalism and romanticism she discovers the village as an oasis of salvation from penetration of wickedness from the city.

Spirit of romanticism is present also in Ida's poetry where she describes and admires of nature in springs, moonlight, beautiful blue color of the sea and sky, silence of Mediterranean south and romantic and majesty of ruins and monuments overgrown with Mediterranean plants:

\section{"Der stille Süd}

Ohne Licht, ohne Luft, ohne Klang

Im Mondeslicht

Und auf dem Meere liegt der Schein

Vom Mondeslicht,

Als solt'er eine Brüche sein

Für's Mondeslicht,

In einer Bucht

Wir sassen auf der Eisterne Rand,

Und hinter uns war die Epheuwand

In der kleinen Bucht, im halben Kreis,

Und vor uns spülte die Meerflut leis.

Im Kloster der Madonna dei Dritti Die Winterlüfte wehen,
Die Winterwolken zieh'n,

Im Bogen der Klosterpforte Blühet der Rosmarin.

Der Steine decken die Höhen, Die Salbei deckt das Gestein, Es scheint ein seidner Teppich Ihr blases Grün zu sein.

\section{Salona}

Es drängen sich üppig Wein und Feigen, Die Traube reifet, der Oelbaum schimmert, Die Ranke klettert, die Distel flimmert,

Die Pappeln wehen - die Steine schweigen. Die zackigen weissen Berge steigen, Der Himmel duftet von frischen Lüften, Die aufgegraben aus grünen Grüften, Die weissen Steine, die ruh'n und schweigen. " [3]

\section{Conclusions}

A travel literature has a didactic role. A person reads and learns something about the country where the journey takes. They can be a source of information for art historians. Of course, sometimes, the information should be checked or taken with caution. But, travel literature also can get into the circle of literature which is of great importance for the history of art history [7].

Some of travel-records is one of the most important and significant travel-records about Dalmatia. In it we can find plenty of data, i.e. numerous topographic notes, descriptions of the soil, cities, streets, buildings, way of life in a certain place, economic relations etc. As those travel-records supply us with a huge amount of visual and written data concerning art in Dalmatia, we can, without any doubt, state that even nowadays some of them are really useful when studying history of Dalmatian art.

Ida is also some kind of the Orientalist. She came in Dalmatia from a country that had just industrialized and she passionately looks for history, culture and disappeared venetians customs. Like real romantic, she sees the village as an oasis of salvation from the invading wickedness of the city and perceives Dalmatia as untouched and primeval nature.

Ida's significance is that she has opened a Dalmatia to a world, and as a cultural and historical landscape and as an unusual and interesting environment. In any case, safe to visit and safe to live.

\section{REFERENCES}

[1] Nada Beritić. Dalmatinske teme Ide Düringsfeld. In: Anali Historijskog instituta Jugoslavenske akademije znanosti i umjetnosti u Dubrovnik. 1970. p. 367-388. 
[2] Ivo Petricioli. Stari Zadar u slici i riječi. Narodni muzej Zadar-Forum. Zadar.1999. p.94-95

[3] Ida von Duringsfeld. Aus Dalmatien. C. Bellman. Prag, 1857.

[4] Krešimir Čvrljak. Ida von Düringsfel-Reinsberg u Skradinu i na Krki (1852.). In: Književna smotra. Br. 89. . god. XXV (1993)

[5] Ivan Pederin. Njemački putopisi po Dalmaciji. Logos. Split. 1989.

[6] Ivo Perić. Boravak Ide Duringsfeld u Dubrovniku. In: Dubrovački horizonti. br. 35. god. 1995.

[7] Marija Stagličić, Povijest povijesti umjetnosti u Dalmaciji u 19. st. In: Zbornik I. kongresa hrvatskih povjesničara umjetnosti (Zagreb, 15.-17. XI. 2001.). 340-342

[8] Miljan Mojašević. Ida Düringsfelds literarische Beziehungen zu den Südslaven. Diewelt der Slaven II Jahrg. Helf 3. Wiesbaden 1957. (303-306)

[9] Matice mrtvih župe Dubrovnik grad 1851-1857. Str. 82-83. Br. 8. U Dubrovačkom arhivu
[10] Ivan Kukuljević-Sakcinski. Stari pisci hrvatski. Knjiga I. Str. XLIX

[11] Marija Stagličić. Barokni ljetnikovac obitelji Lantana na otoku Ugljanu. In: Radovi Instituta povijesti umjetnosti (25/2001). 159-164.

[12] Kruno Prijatelj. Slikarstvo u Dalmaciji od 1784-1884. Knjizevni krug Split. Split. 1989.

[13] Ivan Pederin. Hrvatska, osobito njezino primorje te Hrvatska i Balkan u njemaćkoj lijepoj književnosti. In: Radovi Zavoda JAZU u Zadru. Sv. 26. Zadar 1979. (121-169)

[14] Ivan Pederin. La Dalmazie nelle relazioni di viaggio austriache e tedesche. Aenum. Milano. 49 (1975). Br. 6-7. (499-503)

[15] Ivan Pederin. Starine dalmatinske Hrvatske kao nadahnuće austrijske putopisne književnosti, Biedermeiera, Romantike i Realizma. In: Radovi Filozofskog fakulteta Zadar. Razdio filoloških znanaosti (8) 1974/1975. Sv.13. God. 13. Zadar. 1975. (273-295)

[16] Ivan Pederin.Jadranska Hrvatska u austrijskim i njemačkim putopisima. Nakladni zavod Matice Hrvatske, Zagreb, 1991. 